\title{
O pluralismo religioso em Jacques Dupuis: uma perspectiva teológica para o diálogo inter-religioso ${ }^{1}$
}

Mateus Danieli ${ }^{2}$

\section{Resumo}

O pluralismo religioso de Jacques Dupuis se fundamenta no método indutivo, isto é, da experiência do encontro com a outra religião encontrar o caminho de síntese daquilo que é positivo e dar plausibilidade teológica ao diálogo inter-religioso. O autor fundamenta o paradigma do pluralismo inclusivista como aquele que mais se adéqua as exigências do diálogo, o qual é outra condição para um encontro entre as fés, sem desmerecer uma ou legitimar a outra. Todavia, Dupuis e a teologia do pluralismo religioso foram questionadas pela Santa Sé com dois escritos oficiais que são a Dominus Iesus e a Notificação a Jacques Dupuis. No encontro entre o pluralismo religioso e as críticas ao teólogo em questão surgem desafios fundamentais para a teologia, como sustentar um método teológico que permita o diálogo inter-religioso, um paradigma que evidencie o acolhimento ao diferente e uma insistência no diálogo como caminho para a paz e da tolerância.

Palavras-chaves: Pluralismo Religioso, diálogo inter-religioso, Dupuis, Dominus Iesus, diálogo.

\begin{abstract}
The religious pluralism of Jacques Dupuis is based on the inductive method, that is, from the experience of the encounter with the other religion finding the synthesis way of what is positive and giving theological plausibility to the interreligious dialogue. The author bases the paradigm of inclusivist pluralism as the one that best fits the demands of dialogue, which is another condition for an encounter among faiths, neither demeaning one nor legitimizing the other. However, Dupuis and the theology of religious pluralism were questioned by the Holy See with two official writings, that are Dominus Iesus and the Notification to Jacques Dupuis. In the encounter between religious pluralism and criticism of the theologian under discussion, fundamental challenges for theology arise, such as to support a theological method that allows interreligious dialogue, a paradigm that highlights the acceptance of the different and an insistence on the dialogue as a path to peace and tolerance.
\end{abstract}

Keywords: Religious pluralism, interreligious dialogue, Dupuis, Dominus Iesus, dialogue.

\footnotetext{
${ }^{1}$ Artigo apresentado a disciplina Seminário de Diálogo Inter-religioso no programa de pósgraduação em Teologia da PUCRS sob orientação dos professores Agemir Bavaresco e Rogel Oliveira

${ }^{2}$ Acadêmico do curso de pós-graduação em Teologia PUCRS, graduado em filosofia pela URI Erechim, pós graduado em Espiritualidade pelo Instituto de Teologia e Ciências Humanas, Itepa Faculdades.
} 
Um dos teólogos mais influentes dos últimos tempos em termos de Teologia e Dialogo inter-religioso, pluralismo religioso e ciência das religiões é Jacques Dupuis. É importante localizar Jacques Dupuis em sua trajetória. Nascido na Bélgica tornou-se padre jesuíta e dedicou 25 anos de sua vida, entre os anos 1948 e 1984, ao ensino de teologia sistemática na Índia. O contato com a cultura Hindu permitiu a Dupuis um Sitz Im Leben diferente. Quando retornou a Roma, lecionou Cristologia e Teologia das Religiões na Universidade Gregoriana, responsável pela revista Gregorianum. Participou ativamente na elaboração do documento “Diálogo e Anúncio” para o diálogo inter-religioso do pontificado de João Paulo II. Das obras de Jacques Dupuis destacam-se duas: "Rumo a uma Teologia Cristã do Pluralismo Religioso" e "O Cristianismo e as Religiões: do desencontro ao encontro". Estas obras tiveram duras críticas do Vaticano e exigiram respostas do autor, o que lhe causou muito desgaste.

Apresentado o perfil do autor em questão, o que se pretende com tal pesquisa é refletir sobre os seguintes pontos: em que consiste o Pluralismo Religioso para Dupuis? Porque tanta reação contrária? Quais os desafios para a Teologia? Para tentar responder tais questões, partir-se-á de uma perspectiva analítica em três momentos: 1) O Pluralismo Religioso de Jacques Dupuis; 2) As controvérsias Teológicas; 3) Desafios Teológicos para o diálogo inter-religioso.

\section{Pluralismo religioso em Jacques Dupuis}

A perspectiva do Pluralismo Religioso para Jacques Dupuis é uma nova inspiração própria para o significado do termo em vias teológicas, sem excluir a semântica. O Pluralismo Religioso constitui-se em um princípio de unidade na diversidade das fés vivas das diferentes tradições religiosas, isto é, aquilo que existe de comum nas mais diversas tradições religiosas, na constituição de fé que é comum. Assim, há um novo horizonte no campo da Teologia da Religiões e da Ciência das Religiões. Como explicita Dupuis:

A mudança de terminologia indica uma alteração de perspectiva teológica. A nova perspectiva não é mais limitada ao problema da "salvação" dos membros das outras tradições religiosas, e nem mesmo à questão do papel de tais tradições na salvação dos seus seguidores. Ela busca, com mais profundidade, à luz da fé cristã, o 
significado, no projeto de Deus para a humanidade, da pluralidade das fés vivas e das tradições religiosas que nos cercam. Todas as tradições religiosas do mundo estão destinadas, em tal projeto, a convergir? Onde, quando e como?3

Vê-se então, que a busca do Pluralismo Religioso tem como objetivo encontrar aquilo que, no horizonte do plano de Deus, é comum entre as várias realidades. É o salto qualitativo da preocupação da Teologia das Religiões em debater sobre quem se salva, ou qual é a religião que salva, mas encontrar na pluralidade religiosa o que é desígnio divino e que valoriza o plano de Deus. É o que comenta Rogério Santos Bebber, em sua tese de Mestrado, ao afirmar que: "Para além da constatação do fenômeno da multiplicidade das religiões, uma teologia do pluralismo religioso interroga-se sobre o porquê desta diversidade no desígnio amoroso de Deus" 4 Aqui se retorna ao Sitz Im Leben comentado acima, no qual Depuis realizou sua longa experiência com as tradições religiosas da Índia. Impossível separar a fundamentação dele a respeito do Pluralismo Religioso sem ter em vista a experiência vivida com a religiosidade do povo Hindus 5 .

Para esta nova forma compreensão do Pluralismo Religioso, Dupuis ainda acrescentou que é uma perspectiva plural de direito ou de princípio, que tem sua base na maneira como aquilo que é comum nas tradições religiosas se torna comum entre si sem que elas deixem de ser o que são, mas passam a encontrar o ponto universal entre tantos particulares. Como explica Dupuis:

\footnotetext{
3 DUPUIS, Jacques. Rumo a uma Teologia Cristã do Pluralismo Religioso. São Paulo: Paulinas, 1999, p. 25.

4BEBBER, Rogério Santos. Pluralismo religioso em questão: a teologia de Jacques Dupuis e suas repercussões. Dissertação de Mestrado. Universidade Federal de Juiz de Fora MG, 2012, p. 27. Acesso Online em 31/05/19.

5 "A diversidade religiosa é um dos significativos traços que caracterizam o grande continente asiático. O pluralismo religioso é um dado constitutivo da paisagem asiática, e toca o coração de cada um de seus habitantes. A proximidade com as outras tradições religiosas faz parte do cotidiano dos cristãos que ali habitam, e essa vizinhança tece o modo de viver o cristianismo com uma peculiaridade singular. A riqueza dessa experiểncia de proximidade e amizade foi bem descrita pelos bispos da Asia, em sua primeira assembleia plenária, realizada em Taipé (Taiwan) em abril de 1974. Os bispos reconhecem a relevância das diversas tradições religiosas, enquanto elementos importantes e positivos na economia do plano divino de salvação. Assinalam também o seu respeito e reconhecimento pelos profundos ideais e valores espirituais e éticos que animam tais tradições, traduzindo um valoroso patrimônio de experiência religiosa, de onde os asiáticos tiram força e luz para a sua vida”. Faustino Teixeira, Teologia Asiática e Pluralismo Religioso. IN: Perspectiva Teológica, Belo Horizonte, Ano 43, Número 120, Maio/Agosto 2011, p. 194. Acesso Online em 31/05/19.
} 
A questão não mais consiste, simplesmente, em perguntar-se que papel o Cristianismo pode atribuir às outras tradições religiosas históricas, mas em procurar a raiz do próprio pluralismo, o seu significado no projeto de Deus para a humanidade, a possibilidade de uma convergência das várias tradições, com pleno respeito pelas suas diferenças, o seu mútuo enriquecimento e a sua recíproca fecundidade ${ }^{6}$.

O que se evidencia nesta composição do Pluralismo Religioso é que Dupuis busca sair do senso comum das várias religiões, das várias fés, para encontrar teologicamente aquilo que é convergência. Disto resulta que o teólogo deseja dar um caráter eminentemente teológico para o diálogo inter-religioso, com as vias do pluralismo. Ao aprofundar em sua tese sobre o Pluralismo Religioso em Dupuis, Leandro Santos Bebber explicitou que o Pluralismo de princípio quer dar plausibilidade teológica para o princípio de unidade entre a multiplicidade de religiões, a fim de encontrar um significado positivo para ambas7. E o teólogo Faustino Teixeira reafirma a necessidade do Pluralismo Religioso como uma abertura necessária ao outro e de reconhecimento da verdade do outro. É o que ele diz no livro Teologia das Religiões:

Diante de uma realidade caracterizada pelo pluralismo religioso, não há mais condições de uma perspectiva de entrincheiramento, de fixação num único itinerário, sem se dar conta da singularidade e da riqueza de outros caminhos. A abertura ao outro, a permeabilidade do outro, do diferente como enriquecimento do singular, aparecem na atualidade como passagens imprescindíveis para a construção da identidade 8 .

Deste modo, o posicionamento de Dupuis sobre o Pluralismo Religioso é profundamente pertinente enquanto busca teológica do diálogo inter-religioso. Mas para aprofundar ainda mais este processo, o próprio apresenta o método fundamental para encontrar as raízes teológicas comuns entre as religiões. Tal tema é ponto do próximo ponto.

\footnotetext{
${ }^{6}$ DUPUIS, Jacques. Rumo a uma Teologia Cristã do Pluralismo Religioso. São Paulo: Paulinas, 1999, p. 26.

7 BEBBER, Rogério Santos. Pluralismo religioso em questão: a teologia de Jacques Dupuis e suas repercussões. Dissertação de Mestrado. Universidade Federal de Juiz de Fora MG, 2012, p. 28. Acesso Online em 31/05/19.

8 TEIXEIRA, Faustino. Teologia das Religiões: uma visão panorâmica. São Paulo: Paulinas, 1995, p. 188.
} 


\subsection{Método do Pluralismo Religioso}

Nos livros "Rumo a uma Teologia Cristã do Pluralismo Religioso" e "Pluralismo e as Religiões: do encontro ao desencontro", Jacques Dupuis, logo na introdução de ambas as obras, expõe sua apreciação sobre a metodologia necessária para fundamentar o Pluralismo em chave de diálogo.

Para ele a teologia tradicional usou como método teológico o dogmático dedutivo. Este método consiste em partir de princípios gerais, colhidos da Tradição e da Sagrada Escritura para chegar aos problemas hodiernos ${ }^{9}$. Logo, o método dogmático dedutivo, como a palavra induz, parte daquilo que é dado para responder as preocupações humanas. No que tange a reflexão inter-religiosa, o que é dogmático dedutivo exclui todas as possibilidades de encontrar algo positivo nas outras tradições religiosas, visto ser o dogma superior a uma possibilidade reflexiva. Para Dupuis, o problema do método dogmático dedutivo é que ele se sustenta a priori, fechando-se em si mesmo ${ }^{10}$. Expõe o autor:

O método dogmático foi criticado sobretudo pelo seu caráter abstrato: quanto maior o número de deduções tiradas de princípios abstratos, maior é o risco de sair da realidade. Além disso, o método não dava à mensagem revelada contida na Escritura o lugar que lhe é devido em todo empreendimento teológico ${ }^{11}$.

Diferente do método dedutivo dogmático, o que permite ao Pluralismo Religioso chegar ao seu objetivo de dar plausibilidade teológica ao diálogo entre as religiões é o método indutivo. Este segundo método tem como ponto de partida aquilo que faz parte da realidade das religiões, a fim de verificar o que é dado

\footnotetext{
9 DUPUIS, Jacques. O Cristianismo e as outras religiões: do desencontro ao encontro. São Paulo: Loyola, 2004, p. 25.

10 "O perigo desse método estava no fato de que quanto mais deduções se faziam dos princípios abstratos tanto mais real era o risco de ficarem isoladas na realidade. No que tange à teologia das religiões, partindo-se do dado dogmático da salvação universal da humanidade em Jesus Cristo, fundamentado ele próprio em poucos textos chaves isolados do Novo Testamento (At 4,12; $1 \mathrm{Tm}$ 2,4-5), deduzia-se com surpreendente facilidade a exclusão a priori de qualquer valor salvífico das outras tradições religiosas" IN: DUPUIS, Jacques. O Cristianismo e as outras religiões: do desencontro ao encontro. São Paulo: Loyola, 2004, p. 25

${ }^{11}$ DUPUIS, Jacques. Rumo a uma Teologia Cristã do Pluralismo Religioso. São Paulo: Paulinas, 1999, p. 30.
} 
revelado. Assim, o método permite uma constituição sistemática das questões reais à luz daquilo que é próprio da Teologia ${ }^{12}$.

Este método indutivo foi aplicado com maestria no Concílio Vaticano II. Na Constituição Pastoral Gaudium et Spes a abertura metodológica, e pode-se dizer uma guinada metodológica do Concílio diz o seguinte:

As alegrias e as esperanças, as tristezas e as angústias dos homens de hoje, sobretudo dos pobres e de todos aqueles que sofrem, são também as alegrias e as esperanças, as tristezas e as angústias dos discípulos de Cristo; e não há realidade alguma verdadeiramente humana que não encontre eco no seu coração. Porque a sua comunidade é formada por homens, que, reunidos em Cristo, são guiados pelo Espírito Santo na sua peregrinação em demanda do reino do Pai, e receberam a mensagem da salvação para a comunicar a todos. Por este motivo, a Igreja sente-se real e intimamente ligada ao gênero humano e à sua história (GS 1).

Pelo método dedutivo, a Teologia Conciliar não admitiria a concepção histórica do homem e muito menos o partir da realidade, das alegrias, tristezas, daquilo que o próprio Concílio falou "verdadeiramente humano". Mas como a Gaudium et Spes traz essa abertura, consigo também existe uma mudança metodológica de ver o mundo, a Igreja, a pessoa. Nesta realidade é que se enquadra a possibilidade metodológica de um pluralismo religioso. O teólogo Jacques Dupuis diz que a Constituição Pastoral "aprende a ler os "sinais dos tempos" nas aspirações da humanidade hodierna, e depois procura esclarecer estes problemas e dar uma resposta a estas aspirações, à luz da mensagem do Evangelho" ${ }^{13}$. Dentro desta mudança de ótica metodológica do Concílio, chegou-se a outros dois conceitos importantes para o pluralismo religioso: hermenêutica e contextualização. Segundo Dupuis a realidade interpela a Teologia, é o que se chama de contexto. A luz da Sagrada Escritura, a realidade é lida a partir do texto.

\footnotetext{
12 "Uma reviravolta metodológica representou a progressiva introdução de um método inverso, que pode ser definido como indutivo. No caso desse método, o problema não é mais o de descer dos princípios às aplicações concretas, mas - caminhando na direção oposta - o de tomar como ponto de partida a realidade experimentada atualmente, com todos os problemas que ela levanta, para procurar, à luz da mensagem revelada e mediante a reflexão teológica, uma solução cristã para tais problemas" IN: DUPUIS, Jacques. O Cristianismo e as outras religiões: do desencontro ao encontro. São Paulo: Loyola, 2004, p. 26.

${ }^{13}$ DUPUIS, Jacques. Rumo a uma Teologia Cristã do Pluralismo Religioso. São Paulo: Paulinas, 1999, p. 31.
} 
A interpretação do contexto à luz do texto é a hermenêutica ${ }^{14}$. E o próprio autor explicará que a hermenêutica é feita por um intérprete, que não necessariamente é o teólogo, mas a Igreja, a comunidade de fé que vai interpretando os sinais dos tempos, as realidades que impelem a fé e produzem uma reflexão sistemática disto tudo, função própria da Teologia.

O que é decisivo para o pluralismo religioso e o diálogo inter religioso neste processo todo é o encontro com a realidade. Já que o método indutivo permite este encontro com "aquilo que é histórico" como diz a Gaudium et Spes, o pluralismo religioso encontra ai o seu grande fundamento: a realidade das religiões. Pois não existe como elaborar um discurso sobre as diferentes religiões sem estar inserido em suas realidades, sem propor-se a um diá logos com as diferentes experiências das religiões, ou das diferentes fés. É feliz a explicação do Dupuis a respeito desta necessidade do encontro com o outro:

Considera-se, portanto, decisiva a experiência viva e prolongada da prática do encontro e do diálogo. Não pode ser muito promissora, com efeito, uma reflexão teológica a distância, ou seja, um discurso 'sobre os outros' sem os ter encontrado e ouvido, sem ter estado em contato com o próximo com a vida religiosa e a ‘crença firme' deles....

Esta prática proporciona um novo modo de conceber o diálogo interreligioso e desafia a Teologia a se refazer a partir da síntese do encontro com o outro. Sem esta compreensão metodológica, é impossível entender como Dupuis apresenta o pluralismo religioso em chave teológica. Mas o método teológico em questão possibilita, conforme o teólogo, um espaço profícuo para aproximar as religiões em diálogo, ir ao encontro da fé do outro, perceber o que há de comum com a fé cristã e estabelecer assim raízes teológicas do pluralismo religioso. Nas palavras do próprio autor:

\footnotetext{
14 "O termo texto cobre tudo o que cabe sob o nome de "memória cristã": a tradição objetiva fundada na escritura sagrada. $O$ contexto se refere à realidade complexa que compreende aspectos sociopolíticos, econômicos, culturais e religiosos. Quanto ao interprete, não se trata, a rigor, de cada teólogo, mas da comunidade eclesial a que ele pertence e a cujo serviço está posto" IN: DUPUIS, Jacques. O Cristianismo e as outras religiões: do desencontro ao encontro. São Paulo: Loyola, 2004, p. 27.

${ }^{15}$ DUPUIS, Jacques. O Cristianismo e as outras religiões: do desencontro ao encontro. São Paulo: Loyola, 2004, p. 28.
} 
8 | Opinião Filosófica, V. 10, n. 2, 2019 - Brasil Filosófico e seus pensadores

\begin{abstract}
A teologia das religiões se apresenta como um novo método para fazer teologia. Seu ponto de partida é uma prática de diálogo interreligioso, segundo a qual ela vai à procura de uma interpretação cristã da realidade religiosa plural que a circunda. Apresenta-se também como um novo modo de teologizar. Na realidade, essa teologia não olha para a prática do diálogo inter-religioso simplesmente como para uma condição necessária, para uma premissa ou também para um primeiro passo das próprias ações; ela conserva uma atitude dialógica em cada estágio da sua reflexão: é reflexão teológica sobre o diálogo e no diálogo. $E$ teologia dialógica inter-religiosa ${ }^{16}$.
\end{abstract}

Estabelecido o método do pluralismo religioso, Dupuis apresentará também o paradigma fundamental para tal postura. É o que segue o próximo ponto.

\title{
1.2 Paradigma Pluralista Inclusivista
}

O pluralismo religioso de Jacques Dupuis também aprofunda o tema do paradigma fundamental da Teologia das religiões. O processo de fundamentação do paradigma foi se moldando ao longo da afirmação da própria metodologia teológica do diálogo inter-religioso. O teólogo em questão apresenta três paradigmas e três posições de base, a saber, eclesiocentrismo, cristocentrismo e teocentrismo; exclusivismo, inclusivismo, pluralismo.

O eclesiocentrismo é um paradigma concentrado na perspectiva da salvação em Jesus Cristo e pela fé Católica. A centralidade para o eclesiocentrismo não é demasiadamente a preocupação com a salvação em Jesus Cristo, mas que está é concedida aos que professam a fé na Igreja Católica. Neste paradigma, a posição de base é o exclusivismo. A exclusividade da salvação se dá em uma determinada Igreja. A este respeito Dupuis explicita: "Como a salvação só podia ser conseguida pela fé em Jesus Cristo professada na Igreja, as religiões não cristãs eram, na melhor das hipóteses, tentativas humanas vãs de justificação" ${ }^{17}$. Por este paradigma, o diálogo inter-religioso não existe, porque não há possibilidade de encontrar um caminho de unidade, um ponto de convergência entre ambos.

A passagem do eclesiocentrismo para o cristocentrismo se dá pela posição do Mistério de Jesus Cristo, não mais centrado no Mistério Salvífico de Cristo na

${ }^{16}$ DUPUIS, Jacques. O Cristianismo e as outras religiões: do desencontro ao encontro. São Paulo: Loyola, 2004, p. 29.

${ }_{17}$ DUPUIS, Jacques. Rumo a uma Teologia Cristã do Pluralismo Religioso. São Paulo: Paulinas, 1999, p. 258. 
Igreja, mas no Mistério Salvífico de Cristo. A discussão em torno da salvação não passa pela intermediação eclesial, mas pela ação salvífica realizada por Jesus Cristo. Diz Dupuis: "Para o Novo Testamento, apenas Jesus Cristo é o mediador entre Deus e os seres humanos (cf 1Tm 2,5; Hb 8,6; 9,5; 12,24). Qualquer função que deva ser atribuída à Igreja na ordem da salvação, jamais poderá ser colocada no mesmo nível da função de Jesus Cristo; nem poderá jamais ser-lhe atribuída a mesma necessidade" ${ }^{18}$. Neste paradigma do cristocentrismo encontra-se a base do inclusivismo, visto que amplia o ponto de referência do diálogo para a dimensão cristológica, o que é tranquilo entre religiões cristãs, mas ainda não é o suficiente para um diálogo inter-religioso. O cristocentrismo inclusivista é mais ecumênico do que inter-religioso.

Já para o terceiro paradigma, chamado de teocentrismo, o ponto nevrálgico não está nem na Igreja, nem em Cristo, e sim Deus. É um paradigma bem universalista, pois abre o debate para todas as religiões. Dupuis vai dizer que as religiões são "vias que conduzem a Deus e cada uma delas possui, apesar das diferenças, a mesma validade e valor" ${ }^{19}$. E o teocentrismo se torna pluralista porque abrange o critério da salvação em Deus. Mas para assumir este paradigma é necessário renunciar "qualquer pretensão de unicidade para a pessoa e a obra de Jesus Cristo enquanto elemento constitutivo universal da salvação" ${ }^{20}$. É assumir que Jesus é o salvador para os Cristãos, mas não é o salvador de outros que não são cristãos. Em primeira mão isso é assustador, pois os cristãos precisam abdicar do principio da unicidade da salvação em Jesus para aceitar que os não cristãos também são salvos, mas não por meio de Jesus. Portanto, a Cristologia será um gargalo para pluralismo inclusivista num diálogo interno. Todavia, em uma esteira dialógica ampla, o teocentrismo pluralista acaba sendo o paradigma universal. Como orienta Dupuis:

Assim concebida, a mudança de paradigma do teocentrismo gira inteiramente em torno do problema cristológico. A sua adoção ou a sua rejeição dependem principalmente da aceitação ou da recusa

\footnotetext{
${ }^{18}$ DUPUIS, Jacques. Rumo a uma Teologia Cristã do Pluralismo Religioso. São Paulo: Paulinas, 1999, p 259-260.

${ }_{19}$ DUPUIS, Jacques. Rumo a uma Teologia Cristã do Pluralismo Religioso. São Paulo: Paulinas, 1999, p 260.

${ }^{2}$ DUPUIS, Jacques. Rumo a uma Teologia Cristã do Pluralismo Religioso. São Paulo: Paulinas, 1999, p 260.
} 
10 | Opinião Filosófica, V. 10, n. 2, 2019 - Brasil Filosófico e seus pensadores

de uma cristologia revisionista que se afasta substancialmente do Cristianismo tradicional ${ }^{21}$.

Portanto, o paradigma pluralista inclusivista, mesmo sendo polêmico é uma postura necessária para o diálogo inter-religioso, conforme Dupuis, principalmente num ambiente cultural não cristão. E por falar em diálogo...

\subsection{O Pluralismo inclusivista e o diálogo inter-religioso}

Com o Concílio Vaticano II, a Igreja e a Teologia Católica dão um salto qualitativo na perspectiva do diálogo com as outras religiões não cristãs. A declaração conciliar Nostra Aetate fala do reconhecimento que a Igreja dá as outras religiões, povos e cultura, buscando fomentar a caridade e a unidade. Nas palavras de Paulo VI: "a Igreja considera mais atentamente qual a sua relação com as religiões não-cristãs. E, na sua função de fomentar a união e a caridade entre os homens e até entre os povos, considera primeiramente tudo aquilo que os homens têm de comum e os leva à convivência” (NA 1). E a própria declaração conciliar admite três pontos comuns nas diversas religiões, a saber: que todos tentem a um fim último que é Deus, que todos os homens caminham juntos para a glória de Deus e que todos esperam das religiões respostas para os grandes enigmas humanos, como por exemplo, o sofrimento.

Estes pontos em comum, conforme a declaração conciliar são imbricações teológicas que possibilitam uma aproximação e abrem portas para um diálogo profícuo, visto estarem em sintonia com realidades humanas muito mais do que dogmáticas. Porém, Dupuis observa que esta sintonia e aparente abertura ao diálogo com as outras religiões não cristãs ainda é um tema delicado para o próprio Papa Paulo VI, considerado um homem do diálogo com o mundo moderno ${ }^{22}$.

\footnotetext{
${ }^{21}$ DUPUIS, Jacques. Rumo a uma Teologia Cristã do Pluralismo Religioso. São Paulo: Paulinas, 1999, p 266.

${ }^{22}$ No livro "O Cristianismo e as Religiões: do desencontro ao encontro", Jacques Dupuis cita as encíclicas de Paulo VI após o Concílio como Evangelii Nunciandi e Eclesiam Suam, e que nestas encíclicas o tema do diálogo inter religioso não foi aprofundado com a devida importância. In: DUPUIS, Jacques. O Cristianismo e as outras religiões: do desencontro ao encontro. São Paulo: Loyola, 2004, p. 274.
} 
Um avanço considerável na abertura para o diálogo com as outras religiões não cristãs se deu no pontificado de João Paulo II, quando o Conselho para o diálogo inter religioso publica o documento Dialogo e Anuncio no ano de 1991. Neste documento o presente Conselho conferiu ao diálogo a dimensão primeira, isto é, antes o diálogo, depois o anúncio. Vê-se claramente isso na citação: “O diálogo é o primeiro a ser enfrentado, não por ser prioritária em relação ao anúncio, mas simplesmente pelo fato que o diálogo constitui a principal preocupação do Pontifício Conselho para o Diálogo Inter-Religioso"23. Também, o referido Conselho aprofunda o termo diálogo em três situações integradoras: é necessidade humana, realidade de respeito e abertura ao diferente na dimensão inter-religiosa e plural a qual se está inserido 24.

Para Dupuis, o diálogo é um elemento importante na cultura da evangelização, mas sem a pretensão apologética, ou seja, que ao dialoga com o outro exista a pretensão de converter o outro. O diálogo inter-religioso dirige os interlocutores a encontrarem aquilo que é comum e conduzir ambos os participantes a uma verdadeira fé. Nas palavras de Dupuis: “[...] o diálogo não visa à ‘conversão' dos outros ao cristianismo, mas à convergência dos dois em parceiros do diálogo a uma conversão comum e mais profunda a Deus e aos outros; o anúncio, porém, convida os outros a se tornarem discípulos de Jesus na comunidade cristã" 25 .

Então, o diálogo é pressuposto para a aplicação do método indutivo, próprio da perspectiva do pluralismo religioso. Por meio do diálogo, a outra religião não cristã se torna membro ativo do debate e não o inimigo ao qual se deve vencer.

23 PONTIFÍCIO CONSELHO PARA A EVANGELIZAÇÃO DOS POVOS. Diálogo e Anúncio. 1991. N. 3. Acesso online em 02/06/19.

24 "O diálogo pode ser compreendido de diversos modos. Em primeiro lugar, em nível puramente humano, significa comunicação recíproca, para alcançar um fim comum ou, em um nível mais profundo, uma comunhão interpessoal. Em segundo lugar, o diálogo pode ser considerado como uma atitude de respeito e de amizade, que penetra, ou deveria penetrar, em todas as atividades que constituem a missão evangelizadora da Igreja. Isto pode ser chamado - com razão - "o espírito do diálogo". Em terceiro, num contexto de pluralismo religioso, o diálogo significa "o conjunto das relações inter-religiosas, positivas e construtivas, com pessoas e comunidades de outros credos para um conhecimento mútuo e um recíproco enriquecimento" ( $D M \quad 3$ ), na obediência à verdade e no respeito à liberdade. Isto inclui quer o testemunho quer a ,descoberta das respectivas convicções religiosas. E nesta última acepção que o presente documento utiliza o termo diálogo como um dos elementos integrantes da missão evangelizadora da Igreja". IN: PONTIFÍCIO CONSELHO PARA A EVANGELIZAÇÃO DOS POVOS. Diálogo e Anúncio. 1991. N. 9. Acesso online em 02/06/19.

${ }_{25}$ DUPUIS, Jacques. Rumo a uma Teologia Cristã do Pluralismo Religioso. São Paulo: Paulinas, 1999, p. 275. 
Neste diálogo não existe o um certo e um errado. Cada um é portador da sua verdade religiosa. Desta multiplicidade religiosa se chega a uma síntese, isto é, um terceiro momento do diálogo. A síntese não é o convencimento do outro para a verdade de um, ou a refutação daquilo que o outro acredita, numa posição “diabólica”, dividida. A síntese é o reconhecimento daquilo que possibilita unidade.

Para a perspectiva cristã, um elemento fundamental da síntese do diálogo entre as perspectivas religiosas é a edificação do Reino de Deus anunciado por Jesus Cristo, pois aquilo que Jesus veio anunciar e inaugurar na terra é a mais universal possibilidade de diálogo inclusivo. No Reino de Deus, todos se encontram. É o que afirma com solicitude pastoral a Encíclica Redemptoris Missio de João Paulo II quando afirma:

O Reino de Deus destina-se a todos os homens, pois todos foram chamados a pertencer-lhe. Para sublinhar este aspecto, Jesus aproximou-se sobretudo daqueles que eram marginalizados pela sociedade, dando-lhes preferência, ao anunciar a Boa Nova. No início do Seu ministério, proclama: fui enviado a anunciar a Boa Nova aos pobres (cf. $L c$ 4, 18). As vítimas da rejeição e do desprezo, declara: “ bem-aventurados vós, os pobres" (Lc 6, 20), fazendo-lhes, inclusive, sentir e viver já uma experiência de libertação, estando com eles, partilhando a mesma mesa (cf. Lc 5, $30 ; 15,2$ ), tratando-os como iguais e amigos (cf. Lc 7, 34), procurando que se sentissem amados por Deus, e revelando deste modo imensa ternura pelos necessitados e pecadores (cf. Lc 15, 132) (RM 14).

Para Dupuis, nada mais profundo para o diálogo inter-religioso do que conceber as outras religiões como destinatários do Reino, e não só destinatários, eles são co-participantes desta realidade histórica. Mas só se chega a possibilidade de inclusão dos não cristãos na categoria de co-participantes do Reino de Deus se houver a abertura sincera e honesta ao diálogo ${ }^{26}$.

Porém, assumir o pluralismo religioso como convicção teológica para o diálogo com as religiões não cristãs não é e nem será pacífico. A possibilidade de

\footnotetext{
26 "Nada oferece provavelmente ao diálogo inter-religioso uma base teológica tão profunda e uma motivação tão verdadeira quanto a convicção de que, apesar das diferenças que as distinguem, as pessoas que pertencem às diversas tradições religiosas caminham juntas - membros coparticipantes do Reino de Deus na história - para a plenitude do Reino, para a nova humanidade desejada por Deus para o fim dos tempos, de que são chamadas a serem co-criadoras". IN: DUPUIS, Jacques. Rumo a uma Teologia Cristã do Pluralismo Religioso. São Paulo: Paulinas, 1999, p. 281.
} 
criticas, visões distorcidas, a má compreensão metodológica e a figura emblemática da "verdadeira religião" é real para todo o teólogo que se arrisca neste campo bonito, todavia, espinhoso. Com Jacques Dupuis não foi diferente. Uma declaração da Congregação para Doutrina da Fé abalou as estruturas de Dupuis. Qual será a motivação para tal declaração?

\section{As controvérsias ao pluralismo religioso de Dupuis}

A possibilidade de encontrar o um caminho de diálogo entre as religiões é espinhoso para todos os lados. Geralmente é controverso e polêmico, principalmente quando os participantes do diálogo procuram manter a ortodoxia religiosa da qual são portadores. O teólogo em questão também foi criticado por ter no pluralismo religioso uma via possível e real de síntese entre as religiões.

Dentre os embates religiosos mais acirrados contra Dupuis, apresentam-se dois pronunciamentos oficiais da Santa Sé. Um deles é a Declaração Dominus Iesus sobre unicidade e universalidade salvífica de Jesus e da Igreja, no ano 2000, emitida pelo então prefeito para a Congregação da Doutrina da Fé, Joseph Ratzinger; e a notificação apresentada pela mesma congregação sobre o livro "Para uma teologia cristão do pluralismo religioso" de 1997. O que se segue é uma apresentação destas duas declarações.

\section{1 - Dominus Iesus}

No Ano 2000 a Congregação para a Doutrina da fé emite uma Declaração sobre a unicidade e universalidade salvífica de Jesus e da Igreja. Na época o prefeito da congregação para a doutrina da fé era o cardeal Joseph Ratzinger. Nesta declaração o que se pode observar é que a Igreja Católica reafirma, como fundamento único da salvação, o "Senhor Jesus Cristo". É próprio da Teologia católica, e perfeitamente se aplica a Teologia das Igrejas Cristãs afirmar isto. Como se observa nitidamente no número cinco da referida declaração:

Para fazer frente a essa mentalidade relativista, que se vai difundindo cada vez mais, há que reafirmar, antes de mais, o caráter definitivo e completo da revelação de Jesus Cristo. Deve, de fato, crer-se firmemente na afirmação de que no mistério de Jesus Cristo, Filho de Deus Encarnado, que é “ o caminho, a verdade e a vida" (cf. Jo 14,6), dá-se a revelação da plenitude da 
14 | Opinião Filosófica, V. 10, n. 2, 2019 - Brasil Filosófico e seus pensadores

verdade divina: "Ninguém conhece o Filho senão o Pai e ninguém conhece o Pai senão o Filho e aquele a quem o Filho o queira revelar" (Mt 11,27) (DI 5)

A declaração em questão se posiciona contra a mentalidade relativista, que tem o seu valor em uma afirmação para o mundo cristão que a Revelação Divina e a Salvação humana só são acessíveis por Jesus Cristo. Contudo, uma afirmação como esta em um nível de pluralismo religioso é reduzir a possibilidade diálogo, visto que o método aplicado a Dominus Iesus é, em tese, o método da Teologia Tradicional, isto é, parte-se de afirmações referentes àquilo que se crê, dando-lhe caráter único e universal.

Nesta declaração, há uma possibilidade positiva, na perspectiva do diálogo inter religioso. Mas primeiro reafirma o caráter único e universal da Salvação em Jesus Cristo. "Deve, portanto, crer-se firmemente como verdade de fé católica que a vontade salvífica universal de Deus Uno e Trino é oferecida e realizada de uma vez para sempre no mistério da encarnação, morte e ressurreição do Filho de Deus” (DI 14). Seguida esta afirmação é que vem a possibilidade de afirmação positiva:

Tendo presente este dado de fé, a teologia hoje, meditando na presença de outras experiências religiosas e no seu significado no plano salvífico de Deus, é convidada a explorar se e como também figuras e elementos positivos de outras religiões reentram no plano divino de salvação. Neste empenho de reflexão abre-se à investigação teológica um vasto campo de trabalho sob a guia do Magistério da Igreja (DI 14).

Observa-se uma plausibilidade na condição das outras religiões. Porém, a sequência da Dominus Iesus reintera a afirmação doutrinal a respeito do dado revelado em Jesus Cristo como algo irrevogável para a Teologia, mesmo que isso seja um ponto de estrangulamento para o diálogo inter-religioso. É o que se lê:

Não é raro que se proponha evitar na teologia termos como "unicidade ", " universalidade", " absoluto", cujo uso daria a impressão de se dar uma ênfase excessiva ao significado e valor do evento salvífico de Jesus Cristo em relação às demais religiões. Ora, essa linguagem não faz mais que exprimir a fidelidade ao dado revelado, uma vez que constitui uma evolução das próprias fontes da fé. Desde o início, efetivamente, a comunidade dos crentes atribuiu a Jesus um valor salvífico de tal ordem, que apenas Ele, como Filho de Deus feito homem, crucificado e ressuscitado, por missão recebida do Pai e no poder do Espírito Santo, tem por finalidade dar a revelação (cf. $M t$ 11,27) e a vida 
divina (cf. $J_{0} 1,12 ; 5,25-26 ; 17,2$ ) à humanidade inteira e a cada homem (DI 15).

Para este tema não faltaram críticos e favoráveis. Em uma entrevista ao jornal L'Osservatore Romano o secretário de estado do Vaticano da época, Tarcísio Bertone, ao ser questionado sobre as polêmicas em torno da famigerada declaração e da própria reação do Papa João Paulo II em pedir a Congregação para Doutrina da Fé que formulasse tal declaração, comentou:

Um elemento típico da firmeza doutrinal de João Paulo II diz respeito precisamente à sua paixão por uma cristologia verdadeira, autêntica. O Papa pessoalmente quis a declaração dogmática acerca da unicidade e universalidade salvífica de Jesus Cristo e da Igreja ( Dominus Iesus), não obstante os boatos que atribuíram a uma «insistência» do cardeal Ratzinger ou da Congregação para a Doutrina da Fé o fato de ter desejado esta famosa declaração, boatos que se propagaram inclusive em âmbito católico. Sim, foi o próprio João Paulo II que pediu em primeira pessoa a declaração, porque ficou admirado com as reações críticas à sua Encíclica sobre a missionariedade, Redemptoris Missio, com a qual queria encorajar os missionários a anunciar Cristo também nos contextos onde estão presentes outras religiões, para não diminuir a figura de Jesus a um mero fundador de um movimento religioso. As reações foram negativas, sobretudo na Ásia, e o Papa ficou muito amargurado por isso. Então, no Ano Santo - ano cristológico por excelência - disse: "Por favor, preparai uma declaração dogmática”. Assim foi preparada a Dominus Iesus, densa, simples e com uma linguagem dogmática ${ }^{27}$.

Esclarecedora a fala do Cardeal Bertone a respeito da contextualização da Dominus Iesus. É um pedido do Papa João Paulo II para evidenciar o tom dogmático da fé centrada na Revelação em Jesus Cristo. E continuando a sua fala, Bertone explicita: "Documento esclarece os elementos cristãos essenciais, que não impedem o diálogo, mas mostram as suas bases, porque um diálogo sem fundamentos seria destinado a degenerar em prolixidade vazia. ${ }^{28}$

Para o caminho das críticas ao texto da declaração com certeza não faltaram posicionamentos cítricos em relação ao conteúdo, método e destinatários. Comentando aquilo que percebeu na declaração da Congregação para doutrina da fé, o teólogo Paulo Suess escreveu um artigo chamado “A propósito da

${ }^{27}$ BERTONE, Tarcísio. L’Osservatore Romano, 24/01/2011. Acesso Oline em 02/06/19.
${ }_{28}$ BERTONE, Tarcísio. L’Osservatore Romano, 24/01/2011. Acesso Oline em 02/06/19. 
16 | Opinião Filosófica, V. 10, n. 2, 2019 - Brasil Filosófico e seus pensadores

evangelização explicita: a declaração Dominus Iesus revisitada”, publicada pela revista Perspectiva Teológica. Neste texto Suess considera que:

Ao pluralismo e relativismo pós-modernos, a Dominus Iesus tem poucas respostas: unicidade universal, identidade fundamental e doutrina compacta e compactada, como o chamado Catecismo Universal, agora na forma de um vade-mécum. Sendo assim, a Dominus Iesus dá a tendências relativizantes uma resposta fundamentalista ${ }^{29}$.

Frente a sua crítica, Paulo Suess acrescentou neste artigo que a Dominus Iesus, se não lida na ótica do Concílio Vaticano II que foi a abertura para o reconhecimento das outras religiões, ou seja, para ele a ótica da declaração não está em sintonia com a metodologia do próprio Concílio, voltando a afirmação, se lida em outra ótica "a Igreja Católica abriria mão de sua catolicidade, se isolaria e atestaria a si mesma a incapacidade de dialogar" ${ }^{\circ}$.

Mas até aqui se dedicou um esforço para falar da Dominus Iesus, que é um gérmen de reação à teologia do pluralismo religioso de Jacques Dupuis. Não obstante a toda a doutrinação da declaração, o teólogo do pluralismo ainda foi notificado pessoalmente sobre sua teologia. O que será que aconteceu?

\subsection{A notificação da Congregação para Doutrina da Fé a Jacques Dupuis}

No dia 21 de janeiro de 2011 veio ao público uma notificação formal da Congregação para Doutrina da Fé a respeito do livro "Para uma teologia cristã do Pluralismo Religioso". Tal notificação se tornou um marco na vida e obra de Dupuis, pois exigiu respostas do autor sobre questões teológicas que ficaram mal entendidas ou passiveis de interpretação errônea.

A presente Notificação não quer expressar um juízo sobre o pensamento subjetivo do Autor; mas propõe-se simplesmente enunciar a doutrina da Igreja a respeito de alguns aspectos das supramencionadas verdades doutrinais e, ao mesmo tempo, refutar opiniões errôneas ou perigosas a que, independentemente das intenções do Autor, o leitor possa chegar por causa de

${ }^{29}$ SUESS, PAULO. A propósito da evangelização explicita: a declaração Dominus Iesus revisitada. IN: Perspectiva Teológica, n 37, 2005, p. 411. Acesso Online em 02/06/19. ${ }^{30}$ SUESS, PAULO. A propósito da evangelização explicita: a declaração Dominus Iesus revisitada. IN: Perspectiva Teológica, n 37, 2005, p. 416. Ácesso Online em 02/06/19. 
formulações ambíguas ou explicações insuficientes, contidas em diversos trechos do livro. Deste modo, pensa-se oferecer aos leitores católicos um critério seguro de avaliação, conforme à doutrina da Igreja, com a finalidade de evitar que a leitura da obra possa induzir em graves equívocos e mal-entendidos ${ }^{31}$.

Nesta notificação vários assuntos foram abordados em forma de tópicos, aos quais serão transcritos por tratar-se de chave de leitura: 1) A propósito da mediação salvífica única e universal de Jesus Cristo; 2) A propósito da unicidade e plenitude da revelação de Jesus Cristo; 3) A propósito da ação salvífica universal do Espírito Santo; 4) A propósito da orientação de todos os homens para a Igreja; 5) A propósito do valor e da função salvífica das tradições religiosas.

O processo de assimilação para tal notificação exigiu de Dupuis três anos para elaborar uma resposta. No prefácio do autor da obra "O Cristianismo e as outras religiões: do desencontro ao encontro", Dupuis detalha seu sentimento e recria os passos de tal declaração. Primeiro, cita que tanto a Dominus Iesus quanto a Notificação feita a ele possuem o mesmo assunto e o mesmo propósito que é ressaltar a doutrina católica. Inclusive, Dupuis salienta que os documentos da Congregação partem de uma perspectiva dogmática, com citações escolhidas para fundamentar a ortodoxia teológica da Igreja. Porém, a busca teológica do autor repreendido pela Congregação para a Doutrina da Fé apresenta outro ponto de partida, que segundo ele, se chama "Cristologia trinitária e pneumatológica. Essa perspectiva tem o mérito de ressaltar as inter-relações com o Pai, de um lado, e com o Espírito, de outro - inter-relações intrínsecas ao mistério de Jesus Cristo" ${ }^{2}$. Sobre a Cristologia Trinitária e pneumatológica citada por Dupuis se sustenta muito mais na Teologia Trinitária, relacional e amorosa de Deus Trino do que em um exclusivismo Cristológico de caráter autoritário.

Ao justificar-se, Dupuis também acrescenta que o método buscado por ele para refletir à luz da fé a realidade do Pluralismo Religioso é uma síntese entre o $a$ priori e o a posteriori que resulta em encontrar o que existe de positivo nas diversas realidades religiosas para o plano de salvação universal. Diz Dupuis: "A tarefa da Teologia nesse contexto consiste em perguntar se o pluralismo religioso,

${ }^{31}$ CONGREGAÇÃO PARA DOUTRINA DA FÉ. Notificação a propósito do livro de Jacques Dupuis "Para uma telogia cristã do pluralismo religioso". 24 de Janeiro de 2001. Acesso online em 02/06/19.

${ }^{2}$ DUPUIS, Jacques. Rumo a uma Teologia Cristã do Pluralismo Religioso. São Paulo: Paulinas, 1999, p. 14. 
18 | Opinião Filosófica, V. 10, n. 2, 2019 - Brasil Filosófico e seus pensadores

que caracteriza nosso mundo presente, pode ter ou não um significado positivo no único plano salvífico de Deus para a humanidade” 33 .

Diante do que foi apresentado até agora, as bases do Pluralismo Religioso e as Críticas que Dupuis recebeu sobre sua teologia, quais são os desafios para o fazer teológico?

\section{Pluralismo religioso e os desafios para a teologia}

Mesmo que o diálogo inter-religioso seja um caminho tortuoso, é preciso encontrar saídas para que todo o esforço e dedicação de pessoas como Jacques Dupuis não fique como conteúdo de obras literárias, ou em enfrentamentos eclesiais, ou ainda simplesmente não se trate mais deste tema na Teologia por ter um significado irrelevante. Muito pelo contrário. É dever da Teologia ser assídua nesta área, visto estar mergulhada diretamente na cultura religiosa dos povos, nas tradições genuínas das fés, no mundo cada vez mais global e multifacetado. Mesmo sendo pretensioso, fazem-se interessantes algumas indicações ou prospecções para a Teologia a partir daquilo que foi analisado ao longo deste ensaio. São elas: valor do método teológico, o aprofundamento do paradigma assumido na perspectiva do pluralismo religioso e o próprio diálogo entre as religiões.

\subsection{O Método teológico e o lugar vital}

É notório que o problema entre Dupuis e a Congregação para a doutrina da fé está na opção pelo método teológico. Enquanto que um assume um método indutivo, baseado no encontro com a realidade, na partilha das experiências, em ouvir o que há de positivo no outro e fazer uma síntese disto tudo para ampliar o horizonte do diálogo inter-religioso, o outro método tradicional de viés dedutivo parte de citações da Sagrada Escritura, dos ensinamentos do Magistério e da Tradição Católica.

33 DUPUIS, Jacques. Rumo a uma Teologia Cristã do Pluralismo Religioso. São Paulo: Paulinas, 1999, p.14. 
Na esteira do diálogo inter-religioso não se trata de colocar um método contra o outro e dizer que um é certo e outro é errado. Mas uma síntese entre o $a$ priori e o a posteriori é fundamental, caso contrário, a própria Teologia se esvazia e o diálogo inter-religioso será uma conversa religiosa em tom de apologética, sem jamais contribuir significativamente com o fazer teológico. É o que o próprio Dupuis afirma: "Não há duvida de que a identidade cristã deve ser preservada em sua integridade no processo de encontro e ao se encontrar em diálogo com as outras tradições religiosas. Não há diálogo num vazio ou numa contínua mudança das convicções religiosas pessoais" 34 .

O método para o pluralismo religioso é capaz de garantir que se estabeleça o diálogo, a abertura ao que pensa, reza, canta e louva diferente, sem que haja necessidade de um converter ao outro, pois a adesão por um método produz entre os participantes do diálogo os princípios que, conforme o afirma Dupuis, garantem a plausibilidade teológica do diálogo.

É evidente que a opção pelo método também será parte integrante da experiência vital dos envolvidos. Uma pessoa que não tem convivência com outras culturas religiosas certamente terá dificuldade em encontrar o que há de positivo no outro, e logo haverá uma intenção de convencimento do outro. Já a pessoa que está em um ambiente religioso plural se interessa mais em aprender, dialogar, conhecer, reconhecer o que há de significativo no diferente. Em outras palavras, o Sitz Im Leben é sumamente necessário para a adesão a um método teológico que sintetize as experiências religiosas apontando caminhos oportunos para a Teologia. No caso da controversa entre Dupuis e Santa Sé, o lugar vivencial de um em 25 anos de contato com a realidade Hindu de um lado, e a experiência dogmática daqueles que tinham o dever de manter o "Depositum Fidei" intacto de outro. A diferença de lugar entre Dupuis na Índia e Ratzinger ou João Paulo II no Vaticano é,no mínimo, interessante.

\subsection{O paradigma fundamental}

Ao traduzir o paradigma como um desafio para a teologia do pluralismo

34 DUPUIS, Jacques. Rumo a uma Teologia Cristã do Pluralismo Religioso. São Paulo: Paulinas, 1999, p.15. 
religioso se evidencia aqui uma opção que é consequência da anterior, que é o método. Para refletir teologicamente sobre o pluralismo religioso é impossível partir de um paradigma absoluto, ou como se convencionou entre os teólogos, o exclusivismo. O teólogo que vai se debruçar sobre o tema do Pluralismo Religioso e do diálogo inter-religioso terá que adquirir um paradigma que seja inclusivista e com matiz plural. Há quem diga que para manter este paradigma se há que relativizar a fé em Jesus Cristo, por exemplo, para aceitar o pensamento religioso de outrem. Por outro lado, não há porque relativizar a fé cristã para aceitar o que há de positivo na caminhada religiosa do outro.

Um paradigma que seja exclusivista certamente conduzirá a uma postura apologética, de defesa de verdades confessionais ou de dogmas. Mas para o pluralismo religioso isto certamente será uma barreira, dentre tantas outras naturais que já existem, visto ser elemento de discórdia e não principio de unidade.

Portanto, é prudente que a teologia auxilie a amadurecer sempre mais as bases de um paradigma justo para o dialogo inter-religioso e plural. E com isso abre-se caminhos para uma constante apreciação dos conteúdos dos paradigmas já existentes, ou seja, a construção contínua do paradigma se faz tão necessária quanto a necessidade de abertura e reconhecimento do outro no caminho do pluralismo religioso.

\subsection{Insistir no diálogo por uma cultura de paz e tolerância religiosa}

$\mathrm{Na}$ atual conjuntura mundial, pesa para a Teologia ser uma ciência que auxilie as pessoas de boa vontade a fundamentar no diálogo a cultura da paz. Vê-se claramente isto na postura do Papa Francisco e suas palavras contundentes a respeito da cultura da paz em sua visita aos Emirados Árabes em fevereiro de 2019. No discurso de abertura da sua visita Papa Francisco disse:

Não se pode honrar o Criador sem salvaguardar a sacralidade de cada pessoa e de cada vida humana: cada um é igualmente precioso aos olhos de Deus. Com efeito, Ele não olha a família humana com um olhar de preferência que exclui, mas com um olhar de benevolência que inclui. Por isso, reconhecer os mesmos direitos a todo o ser humano é glorificar o Nome de Deus na terra. 
Assim, em nome de Deus Criador, é preciso condenar, decididamente, qualquer forma de violência, porque seria uma grave profanação do Nome de Deus utilizá-Lo para justificar o ódio e a violência contra o irmão. Religiosamente, não há violência que se possa justificar35.

No Curso anual dos bispos do Brasil de 2017, Dom Miguel Ángel Ayuso Guixot, secretário do Pontifício Conselho para o diálogo inter-religioso, apresentou um texto sobre os ensinamentos do Papa Francisco nesta área. Dom Miguel, entre tantas coisas, disse que nos últimos anos houve um insistente discurso sobre o diálogo pela paz. Mas com o papado de Francisco o tema da paz ganha um novo conceito que é a fraternidade. Nas palavras de Dom Miguel:

Os sinais desta novidade na continuidade se têm manifestado desde o início do seu pontificado. No seu primeiro encontro com os representantes das outras Igrejas e Comunidades eclesiais, do mundo hebraico e das grandes tradições religiosas, o Santo Padre dizia que: "A Igreja Católica é consciente da importância que a promoção da fraternidade e do respeito entre homens e mulheres de diferentes tradições religiosas-isso eu quero repetir: promoção da fraternidade do respeito entre homens e mulheres de diversas tradições religiosas" 36 .

E mais ainda, "a força do diálogo e da colaboração entre as religiões é chamada hoje a fazer frente a uma violência legalmente difusa na nossa sociedade, composta de episódios dramáticos e midiáticos de terrorismo, ou que assume múltiplas formas de exclusão e de racismo em relação àqueles que são considerados diferentes" 37 .

Neste campo tão vasto do diálogo inter-religioso, compete a Teologia e a todos os envolvidos encontrarem as pontes necessárias para uma cultura urgente da tolerância, do respeito de da verdadeira cultura da paz. Este sim é um tema transversal a todas as culturas religiosas em um mundo que vive como já falou o próprio Papa Francisco, uma terceira guerra em etapas.

\footnotetext{
35 Discurso do Papa Francisco em Abu Dhabi em 04/02/19. Acesso online pelo site da rádio Aliança em 03/06/19.

${ }_{36}^{6}$ GUIXOT, D. Miguel Ángel Ayuso. O diálogo inter-religioso nos ensinamentos do Papa Francisco a serviço da paz. IN: Curso Anual dos Bispos do Brasil, 2017, p. 1. Acesso online em 03/06/19.

37 GUIXOT, D. Miguel Ángel Ayuso. O diálogo inter-religioso nos ensinamentos do Papa Francisco a serviço da paz. IN: Curso Anual dos Bispos do Brasil, 2017, p. 4. Acesso online em 03/06/19.
} 


\section{Conclusão}

A perspectiva pluralista defendida por Jacques Dupuis nasce de um contexto de diálogo. Ir ao encontro das diferentes denominações religiosas, superando o senso comum das várias fés e abrir-se a raiz comum das religiões através de uma constituição teológica foi um trabalho árduo desenvolvido pelo autor.

Entretanto, o caminho do diálogo é espinhoso, seja pelas circunstâncias do próprio encontro com a cultura religiosa diferente quanto das críticas internas que isto é capaz de produzir, como aconteceu com o próprio Dupuis ao ser questionado pela Congregação para a Doutrina da fé e a declaração Dominus Iesus. Mesmo que para o Magistério da Igreja a centralidade da Salvação em Jesus Cristo seja o ponto nevrálgico de diálogo, a perspectiva pluralista refletida por Dupuis não entrou em contradição com sua vida de fé e mesmo em contradição com a Teologia Católica Romana.

Quais caminhos se tornam viáveis para um pluralismo religioso em diálogo? Descortinam três pontos, a saber, a necessidade de um Método Teológico que sustente o Diálogo, a fundamentação do paradigma pluralista e sua afirmação como teologicamente necessário e a urgência de uma cultura de tolerância religiosa e a construção da paz. Eis que é tão urgente tudo isso quanto necessário para salvaguardar o diálogo entre as religiões.

\section{Referências}

BEBBER, Rogério Santos. Pluralismo religioso em questão: a teologia de Jacques Dupuis e suas repercussões. Dissertação de Mestrado. Universidade Federal de Juiz de Fora MG, 2012.

BERTONE, Tarcísio. L'Osservatore Romano. 2001. Disponível em: http://www.osservatoreromano.va/pt/news/quando-o-papa-wojtya-quisexplicar-a-dominus-iesus

COMPÊNDIO DO VATICANO II. Constituições, Decretos, Declarações. Petrópolis: Vozes, 2000.

CONGREGAÇÃO PARA DOUTRINA DA FÉ. Declaração sobre a unicidade e universalidade salvífica de Jesus e da Igreja Dominus Iesus. 2000. Disponível em 
<http://www.vatican.va/roman_curia/congregations/cfaith/documents/rc_con_ cfaith_doc_20000806_dominus-iesus_po.html>

CONGREGAÇÃO PARA DOUTRINA DA FÉ. Notificação a propósito do livro de Jacques Dupuis "Para uma teologia cristã do pluralismo religioso". 2001. Disponível

em<http://www.vatican.va/roman_curia/congregations/cfaith/documents/rc_co n_cfaith_doc_20010124_dupuis_po.html>

DUPUIS, Jacques. Rumo a uma Teologia Cristã do Pluralismo Religioso. São Paulo: Paulinas, 1999.

DUPUIS, Jacques. O Cristianismo e as outras religiões: do desencontro ao encontro. São Paulo: Loyola, 2004.

FRANCISCO, Papa. Discurso do Papa Francisco no Encontro Inter-religioso no Founder's Memorial. Abu Dhabi/Emirados Árabes, 4 de fevereiro de 2019. Disponível em <https://noticias.cancaonova.com/especiais/pontificado/francisco/viagensfrancisco/emirados-arabes/papa-em-abu-dhabi-integra-discurso-no-encontrointer-religioso/>.

GUIXOT, D. Miguel Ángel Ayuso. O diálogo inter-religioso nos ensinamentos do Papa Francisco a serviço da paz. IN: Curso Anual dos Bispos do Brasil, 2017. Disponível $<$ http://arqrio.org/files/repository/6 Guixot_3_27012017163730.pdf> em

JOÃO PAULO II, Papa. Carta Encíclica Redemptoris Missio sobre a validade permanente do mandato missionário.1990. Disponível em <http://w2.vatican.va/content/john-paul-ii/pt/encyclicals/documents/hf_jpii_enc_07121990_redemptoris-missio.html>

PONTIFÍCIO CONSELHO PARA A EVANGELIZAÇÃO DOS POVOS. Diálogo e Anúncio. $1991 . \quad$ Disponível em $<$ http://www.vatican.va/roman_curia/pontifical_councils/interelg/documents/rc _pc_interelg_doc_19051991_dialogue-and-proclamatio_po.html>

SUESS, PAULO. A propósito da evangelização explicita: a declaração Dominus Iesus revisitada. IN: Perspectiva Teológica. Disponível em <https://faje.edu.br/periodicos/index.php/perspectiva/article/view/381>

TEIXEIRA, Faustino. Teologia das Religiões: uma visão panorâmica. São Paulo: Paulinas, 1995 .

TEIXEIRA, Faustino. Teologia Asiática e Pluralismo Religioso. IN: Perspectiva Teológica, Belo Horizonte, Ano 43, Número 120, Maio/Agosto 2011. 
24 | Opinião Filosófica, V. 10, n. 2, 2019 - Brasil Filosófico e seus pensadores

Recebido em: 04/11/2019.

Aprovado em: 01/12/2019. 